\title{
Under-Pricing of IPOs in Indian Capital Market and Determinants of Under-Pricing
}

\author{
Dr.M.Appala Raju \\ Department of Management Studies \\ Christ University
}

\begin{abstract}
Organisations in their endeavour to expand diversify and to meet other strategic investment initiatives aim at IPOs (equity) as important source finance. Organisations approach Investment Bankers for pricing the issue which is expected to be well taken by the prospective investors in the market. Equity valuation given by investment bankers very often tend to be overestimated. The equity after the issue tend to be under-priced as the price fixed by the investment bankers is not based on true fundamentals and intrinsic value of the business, but on the inflated values of the company. Irrational investors, keeping the base on the valuations given by the investment bankers tend to lose the value of their investments
\end{abstract}

Key words: Investment banker, Initial Public Offer, Intrinsic Value, Irrational investors, Business valuation .Sources of Finance

\section{INTORDUCTION}

The pricing of an initial public offering (IPO) below its market value. When the offer price is lower than the price of the first trade, the stock is considered to be underpriced. A stock is usually only underpriced temporarily because the laws of supply and demand will eventually drive it toward its intrinsic value.

It is believed that IPOs are often underpriced because of concerns relating to liquidity and uncertainty about the level at which the stock will trade. The less liquid and less predictable the shares are, the more underpriced they will have to be in order to compensate investors for the risk they are taking. Because an IPO's issuer tends to know more about the value of the shares than the investor, a company must underprice its stock to encourage investors to par

All firms need to raise capital at one time or another to finance new projects, expand operations, or in many cases, just to start up their business. One of the best ways that newer and less established companies have found to raise quick capital is to make a stock offering. Initial public offerings (IPOs) have historically had very large initial first day gains compared to the performance of the rest of the market. If we assume that the market price of the stock, dictated by supply and demand, is representative of the company's value, then the large gain reflects the fact that the IPO issuing price agreed upon by the underwriter and the firm making the offer is under the actual value of the firm anticipate in the IPO.

Consequently, many firms make IPOs before they have any basis on which investors can judge them. They have no past revenue records to look at and many have yet to turn a profit before their stock is trading on the exchanges. This is especially true in today's rapidly emerging sectors such as the Internet and technology sectors, where investors do not even have the luxury of looking to the past performance of the industry or finding information about the 
quality and real value of the firm. There exists huge informational asymmetries in the IPO markets, and various economic theories about such markets still argue over who does and does not have the correct information regarding the value of a firm

The most prominent factor in the degree of underpricing has been the uncertainty that exists about the firm making the issue. The information about the firm available to the firm itself, the investors, and the investment bank is key in deciding the degree of underpricing that the IPO will receive. As uncertainty about the firm increases, so does the amount of underpricing, and consequently the initial first day gains are affected by it. To test for this effect, variables will be entered into the empirical model to represent the uncertainty about the firm. Most of the past literature has proclaimed both deal size and issuing firm size as a valid proxy for this. However, actually determining the issuing firm size before an initial public offering can be a problem because of the question of how a firm should be evaluated. Most Internet companies have yet to turn a profit when they make an IPO. In a market with even minimal efficiency, deal size should be a valid proxy for issuing firm size and so only the known deal size variable will be used. As the deal size goes up, the uncertainty involved should go down along with the degree of underpricing.

The underwriters, however, need the uninformed investors to bid since informed investors do not exist in sufficient number. To solve this problem, the underwriter reprices the I.P.O. to bring in these investors and ensure that uninformed investors bid. The consequence is underpricing. This theory has found empirical support in papers that have found that when investment banks can allocate shares in greater measure to informed investors, the underpricing is reduced since the compensation needed to draw uninformed investors is lower. Underpricing has also been found to be lower when information about the issuer is more freely available so that uninformed investors are at less of a disadvantage.

Another informational-based theory for I.P.O. underpricing is known as informational revelation. This theory centers on the book-building process, the mechanism by which an underwriter builds a book of potential investors and the prices and number of shares they are willing to purchase. The book-building process is intended for the underwriter to assess demand and obtain information from potential buyers about what price buyers are willing to pay. In order to incentivize investors to disclose sufficient information about the price they believe is appropriate, underwriters allocate fewer shares to potential purchasers who bid low.

But underwriters still discount the stock to incentivize aggressive bidding and to ensure that the bids are not even lower since the more bids there are, the more information is revealed about the appropriate price for the stock. Issuers accept this underpricing because it allows underwriters to better gauge a higher sale price. This theory too has found empirical support in the academic literature.A third strand of the informational asymmetry theory asserts that underpricing is associated with the weakness of the issuer. The underpricing is intended to compensate the purchasers for this weakness. This theory has found weak evidential support.

The company, meanwhile, received national publicity for its Web site, something that may be worth the tens of millions of dollars alone, if not more.

IPO is considered as an investment tool for the stock market investors. Many investors believe that IPO earn excess returns on the first day of the listing as compared to market returns. Contradictory views are recorded in the literature as few researchers argue that many IPO are overpriced in the market. We assume that the price of IPO is based on demand and supply forces which are achieved through book building process. On this backdrop researchers wants 
to evaluate the pricing efficiency of India IPO's. This examines if IPO's are overpriced, underpriced or fairly priced. It was found that market was not efficient in the period of study. Most of the IPO's were underpriced. Strong relation was found within market condition and return on IPO's. Over scribed shares and IPO return also shows positive relation.

Companied raised capital for new projects, expansion and diversification. IPO's are the one of the popular way to raise the capital through primary market. Many investors believe that IPO earn excess returns on the first day of the listing as compared to the market returns. Contradictory views are recorded in the literature as few researchers argue.

The central question surrounding the IPO underpricing puzzle is why issuers are willing to sell their shares at a price that is less than what the market is willing to pay. This paper shows that a major reason why managers are willing to underprice shares at IPO is that they use options and stock grants to protect themselves from the dilution to their existing shares. Underpricing can have a large positive tax effect for options they hold in addition to making new options more valuable. It show that underpricing shares can increase the tax advantage of paying employees with options. Managers can also use underpriced shares as currency to strengthen strategic alliances and customer loyalty. A major finding of this paper is that the use of options is directly related to IPO underpricing and explains a substantial amount of the variation in firm underpricing.

\section{Age of the firm}

\section{DETERMINANTS WHICH LEAD TO IPO UNDERPRICING}

We assume that an older firm can provide longer operating history than a new firm hence investors can have more trust in the performance of an older firm which in turn reduces the risk and signal a high value of the firm.

\section{Pre IPO leverage}

They measure the market value of the firm a sum of the market value of debt and the market value of equity. The levered and unlevered firms in the same risk class with the same expected return are of the same market value in the equilibrium. Undervalued firm moves up and the overvalued firm share price goes down due to selling pressure thereby making the value of these two firms equal in the equilibrium. Pre IPO leverage indicated high financial distress costs. High agency costs, and also that the firm is not having enough internal financing or profit. Therefore this paper assumes that the value of the highly levered firm is low at the time of IPO.

\section{Issue size}

Issue size was taken as the total number of shares issued in the IPO. Larger issues are subject to regulatory attention and analysed by many analysis therefore they are less risky an so under-pricing is low for larger issues. The model takes issue size as a proxy of supply of the issued shares. The larger issue size increases the supply; therefore in equilibrium the price remains lower.

\section{Promoters holding post issue}

If the promoter holding is high it has less liquidity because promoters holding are the subject of lock in of one year. If the promoter holding is lower, then the issue has higher liquidity. Therefore IPO firms which are having high promoters holding low liquidity are expected to under-price more to attract the investors, 


\section{INDEX RETURN AND INDEX VOLATILITY}

Where good market condition leads to lower under-pricing because good market does not need discount to the investors in terms of under-pricing where good market condition leads to higher under-pricing motivate us to re-examine the market conditions in the Indian IPO market. Therefore the present study takes the index returns and index volatility before the IPO opening as a proxy for market condition. If market return is high then it shows good market condition and if the index volatility is high then it shows high uncertainty in the market.

\section{Sample Size and Sampling Techniques Sampling Method}

Stratified random sampling method was used. A strata was made from the Indian companies who have issued IPO's after 2012 till present.

\section{Sampling Size}

This study employs a data set of 17 companies which consists of the total number of companies who have issued IPOs after 2012.

\section{Sampling Technique}

Regression model: - This model helps in knowing the relationship between the dependent variables and the independent variables.

\section{REVIEW OF LITERATURE}

(Padmavathi, 2012)This article talks about the determinants of underpricing. The study was conducted using models of regression using SPSS tool. IPO's are underpriced under book building mechanism. The results of this research is that investors high willingness to pay, high demand for the issue, high firm value and high fluctuations in the market returns have contributed towards firms underpricing of its IPO's.(Rajib, 2010) This article talks about the two phases of IPO's. Performance has been calculated by adopting two methodologies they are wealth relative technique and buy and hold market adjusted return. Issue price is taken as the base for there calculation.(Rohit Bansal, 2009): The result from the multiple regression implied that there is $48 \%$ variations in the underpricing caused due to age of the firm, issue size, pre ipo leverage, post holdings. The study has more prominent implications for investors who subscribe to different IPOs for listing day gain as this study would help them in understanding which type of firms are more likely to under-priced. (Michelle Lowry, 2008) While significant relations between such characteristics and the initial return have been interpreted as supportive of information asymmetry theory, it is difficult to similarly explain the predictability of the price update. (Ghosh, 2012):-It was found in this research that unceertainity played a very important factor in underpricing.Large issue size and seasoned offerings had very little influence on underpricing.Underpricing was more during the high volume periods of the firm. (DAWSON, 2013):-This article states that an ipo is underpriced on issue. The studies basially studies the difference between the offer price and the issue price. Only a few studies refer to as issuer oriented measures of underpricing. IPOs do not simply have a cost with the opposite sign of the investors' return. Rather, underpriced new shares create a dilutive effect that may make their real cost or wealth transfer much different. (Garfinkel, 2005) Model IPO underpricing is a mechanism for signalling firm quality. The idea behind these theories is that high quality firms have favorable private information about their future prospects that will be at least partially revealed at some future date. (Ritter, 2010):-The changing issuer objective function hypothesis argues that, holding constant the level of managerial ownership and other characteristics, issuing firms became more willing to accept underpricing. (Cook \& T., 2010):- The purpose of this research is to provide additional evidence on the underpricing signaling models by examining the reissuance behavior of 
'second initial public offerings of reverse leveraged buyout (LBO) firms. (CHAMBERS \& DIMSON, 2012):-Central measure of the efficiency of the Initial Public Offering (IPO) market is the extent to which issues are underpriced. We present new and comprehensive evidence covering British IPOs. During the period from 2000 to 2009, public offers were underpriced by an average of only $3.80 \%$, as compared to $9.15 \%$ in the period from 2009 to 2013. (Ellul \& Pagano, 2010):-The underpricing of initial public offerings (IPOs) is generally explained with asymmetric information and risk. We complement these traditional explanations with a new theory where investors worry also about the after-market liquidity that may result from asymmetric information after the IPO. (Philip J. Lee \& Walter*, 2012):- Initial Public Offers (IPOs) made on the Stock Exchange of Singapore routinely provide sufflciently detailed data to allow reconstruction of both the application and allocation schedules. Its show that large investors tend to preferentially request participation in IPOs with higher initial returns, consistent with these investors being better informed.

\section{Bharat Infratel limited}

\section{DATA ANALYSIS AND INTERPRETATION}

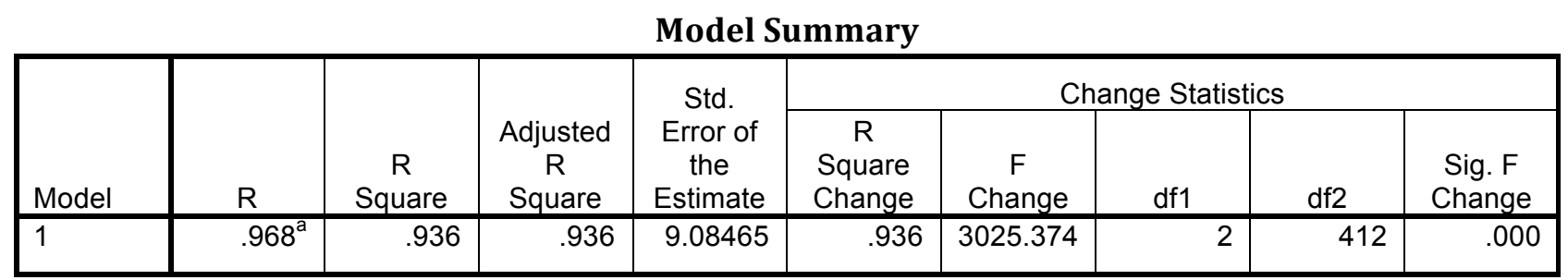

a. Predictors: (Constant), index volatility, Index. Return

This table shows the relationship between the dependent and the independent variables. $\mathrm{R}$ shows that there is $96.8 \%$ correlation between the dependent and the independent variables. $\mathrm{R}$ square which is $93.6 \%$ shows that in Bharat Infratel ipo under-pricing there is a close influence by independent variables towards dependent variables i.e., under-pricing is closely influenced by age of the firm, issue size, pre IPO leverage, promoters holding post issue, Index return and Beta. This model is significant because it has a significance value less than 0.05 i.e., 0.000 .

ANOVAa

\begin{tabular}{|rl|r|r|r|r|r|}
\hline \multicolumn{1}{|l|}{ Model } & & Sum of Squares & Df & Mean Square & \multicolumn{1}{c|}{ F } & \multicolumn{1}{c|}{ Sig. } \\
\hline & Regression & 499373.375 & 2 & 249686.688 & 3025.374 & $.000^{\mathrm{b}}$ \\
1 & Residual & 34002.706 & 412 & 82.531 & & \\
& Total & 533376.081 & 414 & & & \\
\hline
\end{tabular}

a. Dependent Variable: Underprice

b. Predictors: (Constant), index volatility, Index. Return

This table talk about the level of significance the dependent variables are related It has 0.000 degree of significance which states that this model is significant because it is less than 0.05. In this two constraints are kept constant namely Beta and Index return.

The degree of frequency is slightly to be above normal i.e., 2 because normal is considered as 1 . 


\section{Coefficients ${ }^{a}$}

\begin{tabular}{|c|c|c|c|c|c|c|}
\hline \multirow{2}{*}{\multicolumn{2}{|c|}{ Model }} & \multicolumn{2}{|c|}{ Unstandardized Coefficients } & \multirow{2}{*}{$\begin{array}{c}\text { Standardized } \\
\text { Coefficients } \\
\text { Beta }\end{array}$} & \multirow[t]{2}{*}{$\mathrm{t}$} & \multirow[t]{2}{*}{ Sig. } \\
\hline & & $\mathrm{B}$ & Std. Error & & & \\
\hline \multirow{3}{*}{1} & (Constant) & -86.701 & 2.307 & & -37.576 & .000 \\
\hline & Index.return & .937 & .012 & .967 & 77.482 & .000 \\
\hline & Index volitality & 9.075 & 23.272 & .005 & .390 & .697 \\
\hline
\end{tabular}

a. Dependent Variable: Underprice

The findings of the study indicate that the under-pricing increases with significant variables like high return on opening and the beta value. It can now be stated that in capital market, high market conditions under-price more for signalling their high market to their investors. Investors take underpricing as a signal of high market conditions because a low value firm cannot afford leaving money on the table or underpricing. Bharat infratel ipos is affected by market condition therefore leads to underpricing.

\section{Just Dial}

\begin{tabular}{|c|c|c|c|c|c|c|c|c|c|}
\hline \multicolumn{10}{|c|}{ Model Summary } \\
\hline \multirow{2}{*}{ Mode } & \multirow[t]{2}{*}{$\mathrm{R}$} & \multirow{2}{*}{$\begin{array}{c}\mathrm{R} \\
\text { Square }\end{array}$} & \multirow{2}{*}{$\begin{array}{l}\text { Adjusted R } \\
\text { Square }\end{array}$} & \multirow{2}{*}{$\begin{array}{l}\text { Std. Error of } \\
\text { the Estimate }\end{array}$} & \multicolumn{5}{|c|}{ Change Statistics } \\
\hline & & & & & $\begin{array}{c}\text { R Square } \\
\text { Change }\end{array}$ & $\begin{array}{c}\text { F } \\
\text { Change }\end{array}$ & df1 & df2 & $\begin{array}{c}\text { Sig. F } \\
\text { Change }\end{array}$ \\
\hline 1 & $.965^{a}$ & .931 & .931 & 103.17834 & .931 & 2049.615 & 2 & 302 & .000 \\
\hline
\end{tabular}

a. Predictors: (Constant), pre ipo leverage, index volitality

This table shows the relationship between the dependent and the independent variables. $\mathrm{R}$ shows that there is $96.8 \%$ correlation between the dependent and the independent variables. $\mathrm{R}$ square which is $93.6 \%$ shows that in Just dial under-pricing there is a close influence by independent variables towards dependent variables i.e., under-pricing is closely influenced by age of the firm, issue size, pre IPO leverage, promoters holding post issue, Index return and Beta. This model is significant because it has a significance value less than 0.05 i.e., 0.000 .

ANOVAa

\begin{tabular}{|c|c|c|c|c|c|c|}
\hline \multicolumn{2}{|c|}{ Model } & Sum of Squares & Df & Mean Square & $\mathrm{F}$ & Sig. \\
\hline \multirow{3}{*}{1} & Regression & 43639451.776 & 2 & 21819725.888 & 2049.615 & $.000^{\mathrm{b}}$ \\
\hline & Residual & 3215022.668 & 302 & 10645.770 & & \\
\hline & Total & 46854474.444 & 304 & & & \\
\hline
\end{tabular}

a. Dependent Variable: Underpricing

b. Predictors: (Constant), pre ipo leverage, Index.volatility

This table talk about the level of significance and it is less than 0.05 percent therefore which states that the model used is appropriate. 


\begin{tabular}{|c|c|c|c|c|c|c|}
\hline \multicolumn{7}{|c|}{ Coefficients $^{a}$} \\
\hline \multirow{2}{*}{\multicolumn{2}{|c|}{ Model }} & \multicolumn{2}{|c|}{$\begin{array}{c}\text { Unstandardized } \\
\text { Coefficients }\end{array}$} & \multirow{2}{*}{$\begin{array}{c}\text { Standardized } \\
\text { Coefficients } \\
\text { Beta }\end{array}$} & \multirow[t]{2}{*}{$\mathrm{t}$} & \multirow[t]{2}{*}{ Sig. } \\
\hline & & $\mathrm{B}$ & Std. Error & & & \\
\hline \multirow{3}{*}{1} & (Constant) & -163.055 & 20.374 & & -8.003 & .000 \\
\hline & Pre ipo leverage & 1.045 & .016 & .965 & 63.978 & .000 \\
\hline & Index volatility & 31.274 & 149.557 & .003 & .209 & .835 \\
\hline
\end{tabular}

a. Dependent Variable: Underpricing

This tables says that underpricing is caused due to two conditions of the firm i.e., the market and the liquidity conditions. Market conditions involve index volatility and liquidity conditions involve pre ipo leverage. Both do not reflect a high percentage of risk involved to it.

\section{Wonderla Holidays}

\section{Model Summary}

\begin{tabular}{|c|c|c|c|c|c|c|c|c|c|}
\hline \multirow[t]{2}{*}{ Model } & \multirow[t]{2}{*}{$\mathrm{R}$} & \multirow{2}{*}{$\begin{array}{c}\mathrm{R} \\
\text { Square }\end{array}$} & \multirow{2}{*}{$\begin{array}{c}\text { Adjusted R } \\
\text { Square }\end{array}$} & \multirow{2}{*}{$\begin{array}{l}\text { Std. Error of } \\
\text { the Estimate }\end{array}$} & \multicolumn{5}{|c|}{ Change Statistics } \\
\hline & & & & & $\begin{array}{c}\text { R Square } \\
\text { Change }\end{array}$ & $\begin{array}{c}\mathrm{F} \\
\text { Change }\end{array}$ & df1 & df2 & $\begin{array}{c}\text { Sig. F } \\
\text { Change }\end{array}$ \\
\hline 1 & $.922^{\mathrm{a}}$ & .850 & .846 & 14.91438 & .850 & 209.036 & 2 & 74 & .000 \\
\hline
\end{tabular}

a. Predictors: (Constant), Index. Volatility, Index. Return

This table shows the relationship between the dependent and the independent variables. $\mathrm{R}$ shows that there is $92.2 \%$ correlation between the dependent and the independent variables. $\mathrm{R}$ square which is $85 \%$ shows that in Wonderla's IPO underpricing there is a close influence by independent variables towards dependent variables i.e., underpricing is closely influenced by age of the firm, issue size, pre IPO leverage, promoters holding post issue, Index return and Beta. This model is significant because it has a significance value less than 0.05 i.e., 0.000 .

\begin{tabular}{|rl|r|r|r|r|r|}
\hline \multicolumn{1}{|l|}{ Model } & & Sum of Squares & \multicolumn{1}{c|}{ df } & Mean Square & \multicolumn{1}{c|}{$\mathrm{F}$} & Sig. \\
\hline \multirow{2}{*}{1} & Regression & 92995.457 & 2 & 46497.729 & 209.036 & $.000^{\mathrm{b}}$ \\
& Residual & 16460.469 & 74 & 222.439 & & \\
& Total & 109455.926 & 76 & & & \\
\hline
\end{tabular}

a. Dependent Variable: Underprice

b. Predictors: (Constant), Beta, Index.return

This table talk about the level of significance the dependent variables are related it has 0.000 degree of significance which states that this model is significant because it is less than 0.05. In this two constraints are kept constant namely Beta and Index return. The degree of frequency is slightly to be above normal i.e., 2 because normal is considered as 1 . 


\begin{tabular}{|c|c|c|c|c|c|c|}
\hline \multicolumn{7}{|c|}{ Coefficients } \\
\hline \multicolumn{2}{|c|}{ Model } & \multicolumn{2}{|c|}{ Unstandardized Coefficients } & \multirow{2}{*}{$\begin{array}{c}\text { Standardized } \\
\text { Coefficients } \\
\text { Beta }\end{array}$} & \multirow[t]{2}{*}{$\mathrm{t}$} & \multirow[t]{2}{*}{ Sig. } \\
\hline & & $\mathrm{B}$ & Std. Error & & & \\
\hline \multirow{3}{*}{1} & (Constant) & -47.177 & 8.574 & & -5.502 & .000 \\
\hline & Index .return & .770 & .039 & .912 & 19.755 & .000 \\
\hline & Index volatility & 46.696 & 51.276 & .042 & .911 & .365 \\
\hline
\end{tabular}

The findings of the study indicate that the underpricing increases with significant variables like high return on opening and the beta value. It can now be stated that in capital market, high market conditions underprice more for signaling their high market to their investors. Investors take underpricing as a signal of high market conditions because a low value firm cannot afford leaving money on the table or underpricing. Wonderla holidays is affected by market condition therefore leads to underpricing.

\section{Mart}

\begin{tabular}{|c|c|c|c|c|c|c|c|c|c|}
\hline & & & & Model & immary & & & & \\
\hline \multirow[t]{2}{*}{ Model } & \multirow[t]{2}{*}{$\mathrm{R}$} & \multirow{2}{*}{$\begin{array}{c}\mathrm{R} \\
\text { Square }\end{array}$} & \multirow{2}{*}{$\begin{array}{l}\text { Adjusted R } \\
\text { Square }\end{array}$} & \multirow{2}{*}{$\begin{array}{l}\text { Std. Error of } \\
\text { the Estimate }\end{array}$} & \multicolumn{5}{|c|}{ Change Statistics } \\
\hline & & & & & $\begin{array}{c}\text { R Square } \\
\text { Change }\end{array}$ & $\begin{array}{c}\mathrm{F} \\
\text { Change }\end{array}$ & df1 & df2 & $\begin{array}{c}\text { Sig. F } \\
\text { Change }\end{array}$ \\
\hline 1 & $.990^{\mathrm{a}}$ & .981 & .981 & 10.33951 & .981 & 9643.082 & 2 & 372 & .000 \\
\hline
\end{tabular}

a. Predictors: (Constant), promoters holding, pre ipo leverage.

This table shows the relationship between the dependent and the independent variables. $\mathrm{R}$ shows that there is $99 \%$ correlation between the dependent and the independent variables. $\mathrm{R}$ square which is $98.1 \%$ shows that in V-MART underpricing there is a close influence by independent variables towards dependent variables i.e., underpricing is closely influenced by age of the firm, issue size, pre IPO leverage, promoters holding post issue, Index return and Beta. This model is significant because it has a significance value less than 0.05 i.e., 0.000

\begin{tabular}{|rl|r|r|r|r|r|}
\hline \multicolumn{1}{|c|}{ Model } & & Sum of Squares & \multicolumn{1}{c|}{ df } & Mean Square & F & Sig. \\
\hline & Regression & 2061797.422 & 2 & 1030898.711 & 9643.082 & $.000^{\mathrm{b}}$ \\
1 & Residual & 39768.853 & 372 & 106.906 & & \\
& Total & 2101566.275 & 374 & & & \\
\hline
\end{tabular}

Dependent Variable: Underprice

Predictor constant: promoters holding, pre ipo leverage

This table talk about the level of significance the dependent variables are related It has 0.000 degree of significance which states that this model is significant because it is less than 0.05. In this two constraints are kept constant namely Beta and Index return. The degree of frequency is slightly to be above normal i.e., 2 because normal is considered as 1. 


\begin{tabular}{|c|c|c|c|c|c|c|}
\hline \multicolumn{7}{|c|}{ Coefficients $^{a}$} \\
\hline \multirow{2}{*}{\multicolumn{2}{|c|}{ Model }} & \multicolumn{2}{|c|}{$\begin{array}{c}\text { Unstandardized } \\
\text { Coefficients }\end{array}$} & \multirow{2}{*}{$\begin{array}{c}\text { Standardized } \\
\text { Coefficients } \\
\text { Beta }\end{array}$} & \multirow[t]{2}{*}{$\mathrm{t}$} & \multirow[t]{2}{*}{ Sig. } \\
\hline & & $\mathrm{B}$ & Std. Error & & & \\
\hline \multirow{3}{*}{1} & (Constant) & -93.284 & 1.738 & & -53.671 & .000 \\
\hline & Promoters holding & .978 & .007 & .990 & 138.175 & .000 \\
\hline & Pre ipo leverage & 4.104 & 18.115 & .002 & .227 & .821 \\
\hline
\end{tabular}

The findings of the study indicate that the underpricing increases with significant variables like liquidity factors such as promoter's holdings and pre ipo leverage. It can now be stated that in capital market, liquidity conditions influence underprice more for signaling their high market to their investors. Investors take underpricing as a signal of high market conditions because a low value firm cannot afford leaving money on the table or underpricing. V MART is affected by liquidity which ultimately leads to underpricing.

\section{PC. Jewellers}

\begin{tabular}{|c|c|c|c|c|c|c|c|c|c|}
\hline \multicolumn{10}{|c|}{ Model Summary } \\
\hline \multirow{2}{*}{$\begin{array}{l}\text { Mode } \\
\text { I }\end{array}$} & \multirow[t]{2}{*}{$\mathrm{R}$} & \multirow{2}{*}{$\begin{array}{c}\mathrm{R} \\
\text { Square }\end{array}$} & \multirow{2}{*}{$\begin{array}{l}\text { Adjusted R } \\
\text { Square }\end{array}$} & \multirow{2}{*}{$\begin{array}{l}\text { Std. Error of } \\
\text { the Estimate }\end{array}$} & \multicolumn{5}{|c|}{ Change Statistics } \\
\hline & & & & & $\begin{array}{c}\text { R Square } \\
\text { Change }\end{array}$ & $\begin{array}{c}\mathrm{F} \\
\text { Change }\end{array}$ & df1 & df2 & $\begin{array}{c}\text { Sig. F } \\
\text { Change }\end{array}$ \\
\hline 1 & $.954^{\mathrm{a}}$ & .911 & .910 & 7.11293 & .911 & 2105.860 & 2 & 413 & .000 \\
\hline
\end{tabular}

a. Predictors: (Constant), index volatility, Index. Return

This table shows the relationship between the dependent and the independent variables. $\mathrm{R}$ shows that there is $95.4 \%$ correlation between the dependent and the independent variables. $\mathrm{R}$ square which is $91.1 \%$ shows that in PC Jewellers underpricing, there is a close influence by independent variables towards dependent variables i.e., underpricing is closely influenced by age of the firm, issue size, pre IPO leverage, promoters holding post issue, Index return and Beta. This model is significant because it has a significance value less than 0.05 i.e., 0.000 .

\begin{tabular}{|rl|r|r|r|r|r|}
\hline \multicolumn{1}{|c|}{ Model } & Sum of Squares & \multicolumn{1}{c|}{ df } & Mean Square & \multicolumn{1}{c|}{ F } & Sig. \\
\hline & Regression & 213086.979 & 2 & 106543.490 & 2105.860 & $.000^{\mathrm{b}}$ \\
1 & Residual & 20895.248 & 413 & 50.594 & & \\
& Total & 233982.227 & 415 & & & \\
\hline
\end{tabular}
a. Dependent Variable: Underprice
b. Predictors: (Constant), index volatility, Index. Return

This table talk about the level of significance the dependent variables are related it has 0.000 degree of significance which states that this model is significant because it is less than 0.05 . In this two constraints are kept constant namely Beta and Index return. The degree of frequency is slightly to be above normal i.e., 2 because normal is considered as 1 . 


\section{Coefficients}

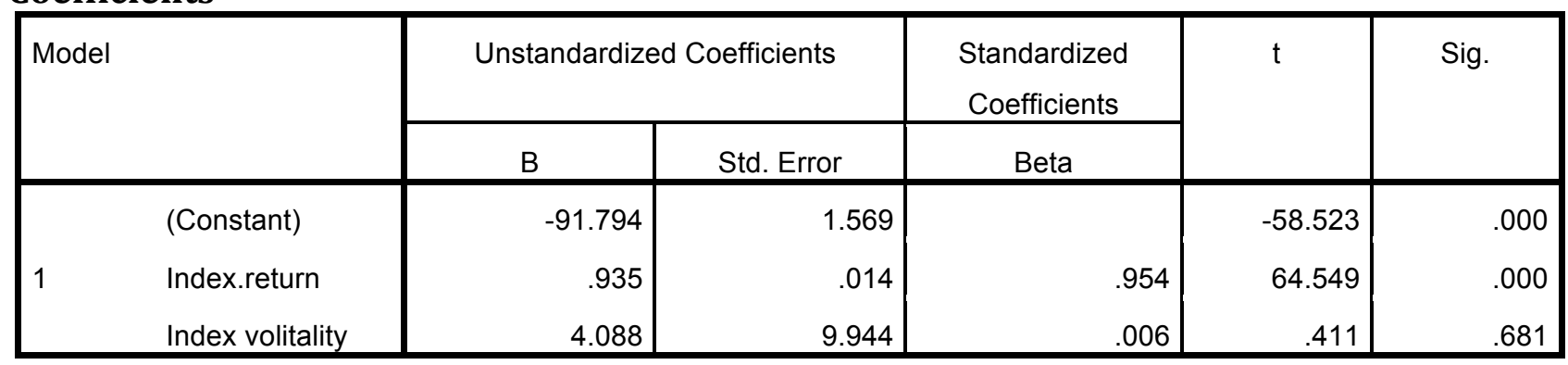

a. Underpricing- dependent variable

The findings of the study indicate that the underpricing increases with significant variables related to market conditions such as index return and index volatility. It can now be stated that in capital market, market conditions influence underprice more for signaling their high market to their investors. Investors take underpricing as a signal of high market conditions because a low value firm cannot afford leaving money on the table or underpricing. PC Jewellers is affected by market condition which ultimately leads to underpricing.

\section{National Building Construction}

\begin{tabular}{|c|c|c|c|c|c|c|c|c|c|}
\hline \multicolumn{10}{|c|}{ Model Summary } \\
\hline \multirow[t]{2}{*}{ Model } & \multirow[t]{2}{*}{$\mathrm{R}$} & \multirow{2}{*}{$\begin{array}{c}\mathrm{R} \\
\text { Square }\end{array}$} & \multirow{2}{*}{$\begin{array}{l}\text { Adjusted R } \\
\text { Square }\end{array}$} & \multirow{2}{*}{$\begin{array}{l}\text { Std. Error of } \\
\text { the Estimate }\end{array}$} & \multicolumn{5}{|c|}{ Change Statistics } \\
\hline & & & & & $\begin{array}{c}\text { R Square } \\
\text { Change }\end{array}$ & F Change & df1 & df2 & $\begin{array}{c}\text { Sig. F } \\
\text { Change }\end{array}$ \\
\hline 1 & $.999^{\mathrm{a}}$ & .999 & .999 & 3.39629 & .999 & 195524.415 & 2 & 562 & .000 \\
\hline
\end{tabular}

a. Predictors: (Constant), age of the firm, index return

This table shows the relationship between the dependent and the independent variables. $\mathrm{R}$ shows that there is $99.9 \%$ correlation between the dependent and the independent variables. $\mathrm{R}$ square which is $99.9 \%$ shows that in national building constructions limited underpricing there is a close influence by independent variables towards dependent variables i.e., underpricing is closely influenced by age of the firm, issue size, pre IPO leverage, promoters holding post issue, Index return and Beta. This model is significant because it has a significance value less than 0.05 i.e., 0.000 .

\begin{tabular}{|rl|r|r|r|r|r|}
\hline \multicolumn{1}{|l|}{ Model } & & ANOVA & \\
\hline & Sum of Squares & Df & Mean Square & \multicolumn{1}{c|}{ F } & Sig. \\
\hline & Regression & 4510671.519 & 2 & 2255335.760 & 195524.415 & $.000^{\mathrm{b}}$ \\
& Residual & 6482.560 & 562 & 11.535 & & \\
& Total & 4517154.079 & 564 & & & \\
\hline
\end{tabular}
a. Dependent Variable: Underpricing
b. Predictors: (Constant), age of the firm, index return

This table talk about the level of significance the dependent variables are related it has 0.000 degree of significance which states that this model is significant because it is less than 0.05. In this two constraints are kept constant namely Beta and Index return. The degree of frequency is slightly to be above normal i.e., 2 because normal is considered as 1 


\begin{tabular}{|c|c|c|c|c|c|c|}
\hline \multicolumn{7}{|c|}{ Coefficients $^{\mathrm{a}}$} \\
\hline \multirow{2}{*}{\multicolumn{2}{|c|}{ Model }} & \multicolumn{2}{|c|}{ Unstandardized Coefficients } & \multirow{2}{*}{$\begin{array}{c}\text { Standardized } \\
\text { Coefficients } \\
\text { Beta }\end{array}$} & \multirow[t]{2}{*}{$\mathrm{t}$} & \multirow[t]{2}{*}{ Sig. } \\
\hline & & $\mathrm{B}$ & Std. Error & & & \\
\hline \multirow{3}{*}{1} & (Constant) & -98.125 & .299 & & -328.175 & .000 \\
\hline & Age of firm & .997 & .002 & .999 & 622.877 & .000 \\
\hline & Index.return & 1.518 & 4.612 & .001 & .329 & .742 \\
\hline
\end{tabular}

a. Dependent Variable: Underpricing

The findings of the study indicate that the under-pricing increases with significant variables related to market condition such as index return and liquidity factor such as age of firm. It can now be stated that in National Building Llimited, market condition and liquidity factor influence underpricing more for signaling their high market to their investors. Investors take underpricing as a signal of high market conditions because a low value firm cannot afford leaving money on the table or underpricing and National Buildings Constructions Limited is affected by market condition which ultimately leads to underpricing.

\section{T Educare}

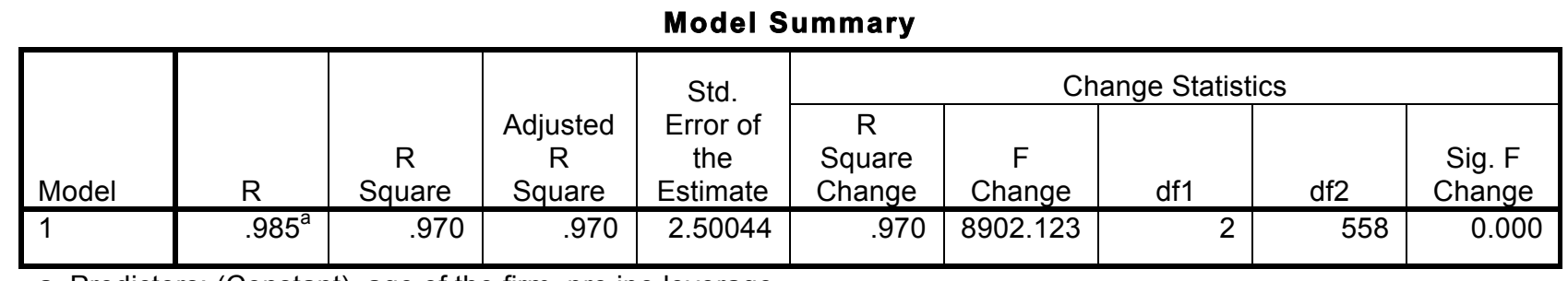

a. Predictors: (Constant), age of the firm, pre ipo leverage

This table shows the relationship between the dependent and the independent variables. $\mathrm{R}$ shows that there is $98.5 \%$ correlation between the dependent and the independent variables. $\mathrm{R}$ square which is $97 \%$ shows that in M T Educare underpricing there is a close influence by independent variables towards dependent variables i.e., underpricing is closely influenced by age of the firm, issue size, pre IPO leverage, promoters holding post issue, Index return and Beta. This model is significant because it has a significance value less than 0.05 i.e., 0.000 .

\begin{tabular}{|c|c|c|c|c|c|c|}
\hline \multicolumn{7}{|c|}{ ANOVAa } \\
\hline & & Sum of Squares & Df & Mean Square & $\mathrm{F}$ & Sig. \\
\hline \multirow{3}{*}{1} & Regression & 111315.347 & 2 & 55657.674 & 8902.123 & $.000^{\mathrm{b}}$ \\
\hline & Residual & 3488.716 & 558 & 6.252 & & \\
\hline & Total & 114804.063 & 560 & & & \\
\hline
\end{tabular}
a. Dependent Variable: Underprrice
b. Predictors: (Constant), age of the firm, pre ipo leverage 
This table talk about the level of significance the dependent variables are related It has 0.000 degree of significance which states that this model is significant because it is less than 0.05. In this two constraints are kept constant namely Beta and Index return. The degree of frequency is slightly to be above normal i.e., 2 because normal is considered as 1.High amount of $\mathrm{F}$ value shows that the model is good.

\begin{tabular}{|c|c|c|c|c|c|c|}
\hline \multicolumn{7}{|c|}{ Coefficients $^{a}$} \\
\hline \multirow{2}{*}{\multicolumn{2}{|c|}{ Model }} & \multicolumn{2}{|c|}{$\begin{array}{c}\text { Unstandardized } \\
\text { Coefficients }\end{array}$} & \multirow{2}{*}{$\begin{array}{c}\text { Standardized } \\
\text { Coefficients } \\
\text { Beta }\end{array}$} & \multirow[t]{2}{*}{$\mathrm{t}$} & \multirow[t]{2}{*}{ Sig. } \\
\hline & & $\mathrm{B}$ & Std. Error & & & \\
\hline \multirow{3}{*}{1} & (Constant) & $\begin{array}{r}- \\
97.092\end{array}$ & .741 & & -130.997 & .000 \\
\hline & Age of firm & .985 & .007 & .985 & 132.644 & .000 \\
\hline & Pre ipo leverage & -2.803 & 3.971 & -.005 & -.706 & .481 \\
\hline
\end{tabular}

The findings of the study indicate that the underpricing increases with significant variables related to value of the firm such as age of firm and pre IPO leverage. It can now be stated that in capital market, value of firm influence underprice more for signaling their high market to their investors. Investors take underpricing as a signal of high market conditions because a low value firm cannot afford leaving money on the table or underpricing. M T Educare is affected by value of firm which ultimately leads to underpricing.

\section{Repco Home Finance Limited}

\begin{tabular}{|c|c|c|c|c|c|c|c|c|c|}
\hline \multicolumn{10}{|c|}{ Model Summary } \\
\hline \multirow[t]{2}{*}{ Model } & \multirow[t]{2}{*}{$\mathrm{R}$} & \multirow{2}{*}{$\begin{array}{c}\mathrm{R} \\
\text { Square }\end{array}$} & \multirow{2}{*}{$\begin{array}{l}\text { Adjusted R } \\
\text { Square }\end{array}$} & \multirow{2}{*}{$\begin{array}{l}\text { Std. Error of } \\
\text { the Estimate }\end{array}$} & \multicolumn{5}{|c|}{ Change Statistics } \\
\hline & & & & & $\begin{array}{l}\text { R Square } \\
\text { Change }\end{array}$ & $\begin{array}{c}\mathrm{F} \\
\text { Change }\end{array}$ & df1 & $\mathrm{df} 2$ & $\begin{array}{c}\text { Sig. F } \\
\text { Change }\end{array}$ \\
\hline 1 & $.698^{\mathrm{a}}$ & .487 & .484 & 70.51072 & .487 & 151.436 & 2 & 319 & .000 \\
\hline
\end{tabular}

a. Predictors: (Constant), Index. Return, pre ipo leverage

This table shows the relationship between the dependent and the independent variables. $\mathrm{R}$ shows that there is $69.8 \%$ correlation between the dependent and the independent variables. $\mathrm{R}$ square which is $48.7 \%$ shows that in Repco home finance limited underpricing there is a close influence by independent variables towards dependent variables i.e., under-pricing is closely influenced by age of the firm, issue size, pre IPO leverage, promoters holding post issue, Index return and Beta. This model is significant because it has a significance value less than 0.05 i.e., 0.000 .

ANOVAa

\begin{tabular}{|c|c|c|c|c|c|c|}
\hline \multicolumn{2}{|c|}{ Model } & Sum of Squares & Df & Mean Square & $\mathrm{F}$ & Sig. \\
\hline \multirow{3}{*}{1} & Regression & 1505810.702 & 2 & 752905.351 & 151.436 & $.000^{b}$ \\
\hline & Residual & 1585991.747 & 319 & 4971.761 & & \\
\hline & Total & 3091802.449 & 321 & & & \\
\hline
\end{tabular}
a. Dependent Variable: Underprice
b. Predictors: (Constant), index return, pre ipo leverage 
This table talk about the level of significance the dependent variables are related it has 0.000 degree of significance which states that this model is significant because it is less than 0.05. In this two constraints are kept constant namely Beta and Index return. The degree of frequency is slightly to be above normal i.e., 2 because normal is considered as 1 .High amount of $F$ value shows that the model is good

\begin{tabular}{|c|c|c|c|c|c|c|}
\hline \multicolumn{7}{|c|}{ Coefficients ${ }^{a}$} \\
\hline \multirow{2}{*}{\multicolumn{2}{|c|}{ Model }} & \multicolumn{2}{|c|}{$\begin{array}{c}\text { Unstandardized } \\
\text { Coefficients }\end{array}$} & \multirow{2}{*}{$\begin{array}{l}\text { Standardized } \\
\text { Coefficients } \\
\text { Beta }\end{array}$} & \multirow[t]{2}{*}{$\mathrm{t}$} & \multirow[t]{2}{*}{ Sig. } \\
\hline & & $\mathrm{B}$ & Std. Error & & & \\
\hline \multirow{3}{*}{1} & (Constant) & -72.872 & 17.009 & & -4.284 & .000 \\
\hline & Index.return & .892 & .051 & .698 & 17.399 & .000 \\
\hline & Pre ipo leverage & 29.043 & 201.617 & .006 & .144 & .886 \\
\hline
\end{tabular}

a. Dependent Variable: Underprice

The findings of the study indicate that the underpricing increases due to factors of liquidity and market condition like index return and pre ipo leverage. Index return has a very high risk involved to it but pre ipo leverage has just 1 percent more than the normal risk ratio. Investors take underpricing as a signal of liquidity and market condition because a low value firm cannot afford leaving money on the table or underpricing. Repco home finance limited is affected by market condition which ultimately leads to underpricing.

\section{Powergrid co. limited}

\begin{tabular}{|c|c|c|c|c|c|c|c|c|c|}
\hline \multicolumn{10}{|c|}{ Model Summary } \\
\hline \multirow[t]{2}{*}{ Model } & \multirow[t]{2}{*}{$\mathrm{R}$} & \multirow{2}{*}{$\begin{array}{c}\mathrm{R} \\
\text { Square }\end{array}$} & \multirow{2}{*}{$\begin{array}{l}\text { Adjusted R } \\
\text { Square }\end{array}$} & \multirow{2}{*}{$\begin{array}{l}\text { Std. Error of } \\
\text { the Estimate }\end{array}$} & \multicolumn{5}{|c|}{ Change Statistics } \\
\hline & & & & & $\begin{array}{l}\text { R Square } \\
\text { Change }\end{array}$ & F Change & df1 & df2 & $\begin{array}{c}\text { Sig. F } \\
\text { Change }\end{array}$ \\
\hline 1 & $.998^{a}$ & .996 & .996 & 1.07789 & .996 & 20699.639 & 2 & 179 & .000 \\
\hline
\end{tabular}

a. Predictors: (Constant), Index. Volatility, Index. Return

This table shows the relationship between the dependent and the independent variables. $\mathrm{R}$ shows that there is $99.8 \%$ correlation between the dependent and the independent variables. $\mathrm{R}$ square which is $99.6 \%$ shows that in Powergrid company limited underpricing there is a close influence by independent variables towards dependent variables i.e., underpricing is closely influenced by age of the firm, issue size, pre IPO leverage, promoters holding post issue, Index return and Beta. This model is significant because it has a significance value less than 0.05 i.e., 0.000

ANOVAa

\begin{tabular}{|rl|r|r|r|r|r|}
\hline \multicolumn{1}{|l|}{ Model } & Sum of Squares & Df & Mean Square & \multicolumn{1}{c|}{ F } & Sig. \\
\hline & Regression & 48099.779 & 2 & 24049.890 & 20699.639 & $.000^{\mathrm{b}}$ \\
& Residual & 207.971 & 179 & 1.162 & & \\
& Total & 48307.751 & 181 & & & \\
\hline
\end{tabular}

a. Dependent Variable: Under-price

b. Predictors: (Constant), index volatility, Index. Return 
This table talk about the level of significance the dependent variables are related It has 0.000 degree of significance which states that this model is significant because it is less than 0.05. In this two constraints are kept constant namely Beta and Index

return. The degree of frequency is slightly to be above normal i.e., 2 because normal is considered as 1 .High amount of $\mathrm{F}$ value shows that the model is good.

\begin{tabular}{|c|c|c|c|c|c|c|}
\hline \multicolumn{7}{|c|}{ Coefficients $^{a}$} \\
\hline \multirow{2}{*}{\multicolumn{2}{|c|}{ Model }} & \multicolumn{2}{|c|}{$\begin{array}{c}\text { Unstandardized } \\
\text { Coefficients }\end{array}$} & \multirow{2}{*}{$\begin{array}{c}\text { Standardized } \\
\text { Coefficients } \\
\text { Beta }\end{array}$} & \multirow[t]{2}{*}{$\mathrm{t}$} & \multirow[t]{2}{*}{ Sig. } \\
\hline & & $\mathrm{B}$ & Std. Error & & & \\
\hline \multirow{3}{*}{1} & (Constant) & -97.028 & .550 & & -176.550 & .000 \\
\hline & Index. Return & .985 & .005 & .998 & 203.280 & .000 \\
\hline & Index volatility & & 5.221 & .002 & .385 & .701 \\
\hline
\end{tabular}

a. Dependent Variable: Underprice

The findings of the study indicate that the underpricing increases with significant variables like high return on opening and the beta value. It can now be stated that in capital market, high market conditions underprice more for signaling their high market to their investors. Investors take underpricing as a signal of high market conditions because a low value firm cannot afford leaving money on the table or underpricing. Powergrid Company ipos are affected by market condition therefore leads to underpricing

\section{Tara jewels limited}

\begin{tabular}{|c|c|c|c|c|c|c|c|c|c|}
\hline \multirow[b]{3}{*}{ Model } & \multirow[b]{3}{*}{$\mathrm{R}$} & \multicolumn{7}{|c|}{ Model Summary } & \\
\hline & & \multirow[b]{2}{*}{$\begin{array}{c}\mathrm{R} \\
\text { Square }\end{array}$} & \multirow[b]{2}{*}{$\begin{array}{l}\text { Adjusted R } \\
\text { Square }\end{array}$} & \multirow[b]{2}{*}{$\begin{array}{l}\text { Std. Error of the } \\
\text { Estimate }\end{array}$} & \multicolumn{5}{|c|}{ Change Statistics } \\
\hline & & & & & $\begin{array}{l}\text { R Square } \\
\text { Change }\end{array}$ & F Change & df1 & df2 & $\begin{array}{c}\text { Sig. } F \\
\text { Change }\end{array}$ \\
\hline 1 & $.921^{\mathrm{a}}$ & .848 & .847 & 17.98373 & .848 & 1187.183 & 2 & 425 & .000 \\
\hline
\end{tabular}

a. Predictors: (Constant), promoters holdings, pre ipo leverage

This table shows the relationship between the dependent and the independent variables. $\mathrm{R}$ shows that there is $92.1 \%$ correlation between the dependent and the independent variables. $\mathrm{R}$ square which is $84.8 \%$ shows that in Tara jewels limited under-pricing there is a close influence by independent variables towards dependent variables i.e., under-pricing is closely influenced by age of the firm, issue size, pre IPO leverage, promoters holding post issue, Index return and Beta. This model is significant because it has a significance value less than 0.05 i.e., 0.000 .

\begin{tabular}{|rl|r|r|r|r|r|}
\hline \multicolumn{1}{|c|}{ ANOVA $^{\text {Model }}$} & \multicolumn{1}{c|}{ Sig. } \\
\hline \multirow{2}{*}{1} & Regression & 767904.298 & 2 & 383952.149 & 1187.183 & $.000^{\mathrm{b}}$ \\
& Residual & 137451.121 & 425 & 323.414 & & \\
& Total & 905355.420 & 427 & & & \\
\hline
\end{tabular}
a. Dependent Variable: Under-price
b. Predictors: (Constant), promoters holding, pre ipo leverage 
This table talk about the level of significance the dependent variables are related It has 0.000 degree of significance which states that this model is significant because it is less than 0.05. In this two constraints are kept constant namely Beta and Index

return. The degree of frequency is slightly to be above normal i.e., 2 because normal is considered as 1.High amount of $\mathrm{F}$ value shows that the model is good.

Coefficients $^{\mathrm{a}}$

\begin{tabular}{|c|c|c|c|c|c|c|}
\hline \multirow{2}{*}{\multicolumn{2}{|c|}{ Model }} & \multicolumn{2}{|c|}{$\begin{array}{c}\text { Unstandardized } \\
\text { Coefficients }\end{array}$} & \multirow{2}{*}{$\begin{array}{c}\text { Standardized } \\
\text { Coefficients } \\
\text { Beta } \\
\end{array}$} & \multirow[t]{2}{*}{$\mathrm{t}$} & \multirow[t]{2}{*}{ Sig. } \\
\hline & & $\mathrm{B}$ & Std. Error & & & \\
\hline \multirow{3}{*}{1} & (Constant) & 92.149 & 2.552 & & -36.106 & .000 \\
\hline & Promoters holding & .935 & .019 & .921 & 48.727 & .000 \\
\hline & Pre ipo leverage & 13.744 & 26.167 & -.010 & -.525 & .600 \\
\hline
\end{tabular}

a. Dependent Variable: Under-price

The findings of the study indicate that the underpricing increases with significant variables like promoters holding and pre ipo leverage which constitutes market conditions. It can now be stated that in capital market, high market conditions underprice more for signaling their high market to their investors. Investors take underpricing as a signal of high market conditions because a low value firm cannot afford leaving money on the table or underpricing. Tara jewels limited IPOs are affected by market condition therefore leads to underpricing.

\section{VKS Project limited}

Model Summary

\begin{tabular}{|c|c|c|c|c|c|c|c|c|c|}
\hline \multirow[t]{2}{*}{ Model } & \multirow[t]{2}{*}{$\mathrm{R}$} & \multirow{2}{*}{$\begin{array}{c}\mathrm{R} \\
\text { Square }\end{array}$} & \multirow{2}{*}{$\begin{array}{c}\text { Adjusted R } \\
\text { Square }\end{array}$} & \multirow{2}{*}{$\begin{array}{l}\text { Std. Error of } \\
\text { the Estimate }\end{array}$} & \multicolumn{5}{|c|}{ Change Statistics } \\
\hline & & & & & $\begin{array}{c}\text { R Square } \\
\text { Change }\end{array}$ & $\begin{array}{c}\mathrm{F} \\
\text { Change }\end{array}$ & df1 & df2 & $\begin{array}{c}\text { Sig. F } \\
\text { Change }\end{array}$ \\
\hline 1 & $.974^{\mathrm{a}}$ & .949 & .949 & 17.16159 & .949 & 4806.959 & 2 & 519 & .000 \\
\hline
\end{tabular}

a. Predictors: (Constant), index volatility, Index.return

This table shows the relationship between the dependent and the independent variables. $\mathrm{R}$ shows that there is $97.4 \%$ correlation between the dependent and the independent variables. $\mathrm{R}$ square which is $94.9 \%$ shows that in VKS Project limited underpricing there is a close influence by independent variables towards dependent variables i.e., underpricing is closely influenced by age of the firm, issue size, pre IPO leverage, promoters holding post issue, Index return and Beta. This model is significant because it has a significance value less than 0.05 i.e., 0.000 .

ANOVAa

\begin{tabular}{|rl|r|r|r|r|r|}
\hline \multicolumn{1}{|c|}{ Model } & Sum of Squares & Df & Mean Square & \multicolumn{1}{c|}{ F } & Sig. \\
\hline & Regression & 2831493.778 & 2 & 1415746.889 & 4806.959 & $.000^{\mathrm{b}}$ \\
1 & Residual & 152856.026 & 519 & 294.520 & & \\
& Total & 2984349.805 & 521 & & & \\
\hline
\end{tabular}

a. Dependent Variable: Under-price

b. Predictors: (Constant), index volatility, Index. Return 
This table talk about the level of significance the dependent variables are related it has 0.000 degree of significance which states that this model is significant because it is less than 0.05. In this two constraints are kept constant namely Beta and Index return. The degree of frequency is slightly to be above normal i.e., 2 because normal is considered as 1 .High amount of $F$ value shows that the model is good.

Coefficients ${ }^{\mathrm{a}}$

\begin{tabular}{|c|c|c|c|c|c|c|}
\hline \multirow{2}{*}{\multicolumn{2}{|c|}{ Model }} & \multicolumn{2}{|c|}{$\begin{array}{c}\text { Unstandardized } \\
\text { Coefficients }\end{array}$} & \multirow{2}{*}{$\begin{array}{c}\text { Standardized } \\
\text { Coefficients } \\
\text { Beta }\end{array}$} & \multirow[t]{2}{*}{$\mathrm{t}$} & \multirow[t]{2}{*}{ Sig. } \\
\hline & & $\mathrm{B}$ & Std. Error & & & \\
\hline \multirow{3}{*}{1} & (Constant) & -95.970 & .864 & & -111.076 & .000 \\
\hline & Index. Return & 1.009 & .010 & .974 & 97.704 & .000 \\
\hline & Index volatility & & 9.706 & -.002 & -.223 & .823 \\
\hline
\end{tabular}

a. Dependent Variable: Under-price

The findings of the study indicate that the under-pricing increases with significant variables like high return on opening and the beta value. It can now be stated that in capital market, high market conditions under-price more for signalling their high market to their investors. Investors take underpricing as a signal of high market conditions because a low value firm cannot afford leaving money on the table or underpricing. VKS Project limited ipos are affected by market condition therefore leads to underpricing.

\section{Speciality Restaurants limited}

\begin{tabular}{|c|c|c|c|c|c|c|c|c|c|}
\hline \multicolumn{10}{|c|}{ Model Summary } \\
\hline \multirow{2}{*}{ Mode } & \multirow[t]{2}{*}{$\mathrm{R}$} & \multirow{2}{*}{$\begin{array}{c}\mathrm{R} \\
\text { Square }\end{array}$} & \multirow{2}{*}{$\begin{array}{l}\text { Adjusted R } \\
\text { Square }\end{array}$} & \multirow{2}{*}{$\begin{array}{l}\text { Std. Error of } \\
\text { the Estimate }\end{array}$} & \multicolumn{5}{|c|}{ Change Statistics } \\
\hline & & & & & $\begin{array}{l}\text { R Square } \\
\text { Change }\end{array}$ & $\begin{array}{c}\mathrm{F} \\
\text { Change }\end{array}$ & df1 & df2 & $\begin{array}{l}\text { Sig. F } \\
\text { Change }\end{array}$ \\
\hline 1 & $.957^{\mathrm{a}}$ & .917 & .916 & 7.92838 & .917 & 3056.057 & 2 & 556 & .000 \\
\hline
\end{tabular}

a. Predictors: (Constant), pre ipo leverage, promoters holding

This table talks about the relationship and impact each causes between the dependent and the independent variables. $\mathrm{R}$ shows that there is $95.7 \%$ relationship between the dependent and the independent variables i.e., impact of underpricing caused due to age of the, issue size, pre ipo leverage, promoters holding post issue, index return and index volatility. R square shows that independent variables have $91.7 \%$ impact on dependent variables.

ANOVAa

\begin{tabular}{|rl|r|r|r|r|r|}
\hline \multicolumn{1}{|l|}{ Model } & & Sum of Squares & Df & Mean Square & \multicolumn{1}{c|}{ F } & Sig. \\
\hline & Regression & 384202.335 & 2 & 192101.167 & 3056.057 & $.000^{\mathrm{b}}$ \\
1 & Residual & 34949.686 & 556 & 62.859 & & \\
& Total & 419152.021 & 558 & & & \\
\hline
\end{tabular}

a. Dependent Variable: Under-price

b. Predictors: (Constant), pre ipo leverage, promoters holding

This analyses shows that the model is significant because it has a significance value of 0.00 which is less than 0.05 . The $F$ value shows a high value which states the overall variables relationship with the dependent variables. 


\section{Correlation}

\begin{tabular}{|c|c|c|c|c|c|c|}
\hline \multirow[t]{2}{*}{ Mode } & & \multicolumn{2}{|c|}{$\begin{array}{c}\text { Unstandardized } \\
\text { Coefficients }\end{array}$} & \multirow{2}{*}{$\begin{array}{c}\text { Standardized } \\
\text { Coefficients }\end{array}$} & \multirow[t]{2}{*}{$\mathrm{t}$} & \multirow[t]{2}{*}{ Sig. } \\
\hline & & B & Std. Error & & & \\
\hline \multirow{3}{*}{1} & (Constant) & -98.428 & 1.988 & & -49.515 & .000 \\
\hline & Pre ipo leverage & .993 & .013 & .958 & 78.064 & .000 \\
\hline & Promoters holding & -14.542 & 13.926 & -.013 & -1.044 & .297 \\
\hline
\end{tabular}

a. Dependent Variable: Under-price

This table shows clearly that the market conditional factors that are contributing to underpricing of the firm. Liquidity factors include pre ipo leverage and promoters holding in post issue equity. Therefore the result here is that the liquidity condition of the firm contributes to the underpricing of speciality restaurants limited.

\section{CARE}

\begin{tabular}{|c|c|c|c|c|c|c|c|c|c|}
\hline \multicolumn{10}{|c|}{ Model Summary } \\
\hline \multirow[t]{2}{*}{ Model } & \multirow[t]{2}{*}{$\mathrm{R}$} & \multirow{2}{*}{$\begin{array}{c}\mathrm{R} \\
\text { Square }\end{array}$} & \multirow{2}{*}{$\begin{array}{l}\text { Adjusted R } \\
\text { Square }\end{array}$} & \multirow{2}{*}{$\begin{array}{l}\text { Std. Error of } \\
\text { the Estimate }\end{array}$} & \multicolumn{5}{|c|}{ Change Statistics } \\
\hline & & & & & $\begin{array}{l}\text { R Square } \\
\text { Change }\end{array}$ & $\begin{array}{c}\text { F } \\
\text { Change }\end{array}$ & df1 & df2 & $\begin{array}{l}\text { Sig. F } \\
\text { Change }\end{array}$ \\
\hline 1 & $.907^{\mathrm{a}}$ & .823 & .822 & 81.99156 & .823 & 960.316 & 2 & 413 & .000 \\
\hline
\end{tabular}

a. Predictors: (Constant), index volatility, Index. Return

This table talks about the relationship and impact each causes between the dependent and the independent variables. $\mathrm{R}$ shows that there is $90.7 \%$ relationship between the dependent and the independent variables i.e., impact of underpricing caused due to age of the, issue size, pre ipo leverage, promoters holding post issue, index return and index volatility. R square shows that independent variables have $82.3 \%$ impact on dependent variables

\begin{tabular}{|rl|r|r|r|r|r|}
\hline \multicolumn{1}{|l|}{ Model } & & Sum of Squares & \multicolumn{1}{|c|}{ Df } & Mean Square & \multicolumn{1}{c|}{ F } & Sig. \\
\hline \multirow{4}{*}{1} & Regression & 12911674.785 & 2 & 6455837.393 & 960.316 & $.000^{\mathrm{b}}$ \\
& Residual & 2776440.199 & 413 & 6722.615 & & \\
& Total & 15688114.984 & 415 & & & \\
\hline
\end{tabular}

a. Dependent Variable: Underpricing

b. Predictors: (Constant), index volatility, Index. Return

This analyses shows that the model is significant because it has a significance value of 0.00 which is less than 0.05 . The $F$ value shows a high value which states the overall variables relationship with the dependent variables. 


\section{Coefficients}

\begin{tabular}{|c|c|c|c|c|c|c|c|c|}
\hline \multirow{2}{*}{\multicolumn{2}{|c|}{ Model }} & \multicolumn{2}{|c|}{ Unstandardized Coefficients } & \multirow{2}{*}{$\begin{array}{l}\text { Standardized } \\
\text { Coefficients } \\
\text { Beta }\end{array}$} & \multirow[t]{2}{*}{$\mathrm{t}$} & \multirow[t]{2}{*}{ Sig. } & \multicolumn{2}{|c|}{ Collinearity Statistics } \\
\hline & & B & Std. Error & & & & Tolerance & VIF \\
\hline \multirow{3}{*}{1} & (Constant) & -90.286 & 18.025 & & -5.009 & .000 & & \\
\hline & Index.return & .984 & .023 & .908 & 43.648 & .000 & .990 & 1.010 \\
\hline & $\begin{array}{l}\text { Index } \\
\text { volatility }\end{array}$ & -106.277 & 203.875 & -.011 & -.521 & .602 & .990 & 1.010 \\
\hline
\end{tabular}

a. Dependent Variable: Underpricing

The findings of the study indicate that the underpricing increases with significant variables like high return on opening and the beta value. It can now be stated that in capital market, high market conditions underprice more for signalling their high market to their investors. Investors take underpricing as a signal of high market conditions because a low value firm cannot afford leaving money on the table or underpricing. Bharat Infratel IPO are affected by market condition therefore leads to underpricing.

\section{Tribhovandas bhimji zaveri}

\begin{tabular}{|c|c|c|c|c|c|c|c|c|c|}
\hline \multirow[t]{2}{*}{ Model } & \multirow[t]{2}{*}{$\mathrm{R}$} & \multirow{2}{*}{$\begin{array}{c}\mathrm{R} \\
\text { Square }\end{array}$} & \multirow{2}{*}{$\begin{array}{l}\text { Adjusted R } \\
\text { Square }\end{array}$} & \multirow{2}{*}{$\begin{array}{l}\text { Std. Error of } \\
\text { the Estimate }\end{array}$} & \multicolumn{5}{|c|}{ Change Statistics } \\
\hline & & & & & $\begin{array}{l}\text { R Square } \\
\text { Change }\end{array}$ & F Change & df1 & df2 & $\begin{array}{c}\text { Sig. F } \\
\text { Change }\end{array}$ \\
\hline 1 & $.998^{\mathrm{a}}$ & .997 & .997 & 2.70937 & .997 & 91748.663 & 2 & 571 & .000 \\
\hline
\end{tabular}

a. Predictors: (Constant), index volatility, Index. Return

This table talks about the relationship and impact each causes between the dependent and the independent variables. $\mathrm{R}$ shows that there is $99.8 \%$ relationship between the dependent and the independent variables i.e., impact of underpricing caused due to age of the, issue size, pre ipo leverage, promoters holding post issue, index return and index volatility. R square shows that independent variables have $99.7 \%$ impact on dependent variables.

\begin{tabular}{|rl|r|r|r|r|r|}
\hline \multicolumn{1}{|c|}{ ANOVA $^{\mathrm{a}}$} \\
\hline & Sum of Squares & \multicolumn{1}{c|}{ Df } & Mean Square & \multicolumn{1}{c|}{ F } & \multicolumn{1}{c|}{ Sig. } \\
\hline & Regression & 1346992.021 & 2 & 673496.011 & 91748.663 & $.000^{\mathrm{b}}$ \\
& Residual & 4191.519 & 571 & 7.341 & & \\
& Total & 1351183.540 & 573 & & & \\
\hline
\end{tabular}

a. Dependent Variable: Underpricing

b. Predictors: (Constant), index volatility, Index. Return

This analyses shows that the model is significant because it has a significance value of 0.00 which is less than 0.05 . The $F$ value shows a high value which states the overall variables relationship with the dependent variables. 
Coefficients $^{a}$

\begin{tabular}{|c|c|c|c|c|c|c|c|c|}
\hline \multirow{2}{*}{\multicolumn{2}{|c|}{ Model }} & \multicolumn{2}{|c|}{ Unstandardized Coefficients } & \multirow{2}{*}{$\begin{array}{c}\text { Standardized } \\
\text { Coefficients } \\
\text { Beta }\end{array}$} & \multirow[t]{2}{*}{$\mathrm{t}$} & \multirow[t]{2}{*}{ Sig. } & \multicolumn{2}{|c|}{ Collinearity Statistics } \\
\hline & & B & Std. Error & & & & Tolerance & VIF \\
\hline \multirow{3}{*}{1} & (Constant) & -99.996 & .406 & & -246.345 & .000 & & \\
\hline & Index.return & 1.005 & .002 & .999 & 427.839 & .000 & .997 & 1.003 \\
\hline & $\begin{array}{l}\text { Index } \\
\text { volatility }\end{array}$ & -4.589 & 3.246 & -.003 & -1.414 & .158 & .997 & 1.003 \\
\hline
\end{tabular}

a. Dependent Variable: Underpricing

The findings of the study indicate that the underpricing increases with significant variables like high return on opening and the beta value. It can now be stated that in capital market, high market conditions underprice more for signaling their high market to their investors. Investors take underpricing as a signal of high market conditions because a low value firm cannot afford leaving money on the table or underpricing. Tribhovandas bhimji zaveri is affected by market condition therefore leads to underpricing.

\section{L\&T Finance Holdings}

\begin{tabular}{|l|r|r|r|r|r|r|r|r|r|}
\hline Mode & $\mathrm{R}$ & $\mathrm{R}$ & Adjusted R \\
$\mathrm{I}$
\end{tabular}

a. Predictors: (Constant), age of the firm, pre ipo leverage

This table talks about the relationship and impact each causes between the dependent and the independent variables. $\mathrm{R}$ shows that there is $84.3 \%$ relationship between the dependent and the independent variables i.e., impact of underpricing caused due to age of the, issue size, pre ipo leverage, promoters holding post issue, index return and index volatility. R square shows that independent variables have $71.1 \%$ influence on dependent variables.

ANOVAa

\begin{tabular}{|rl|r|r|r|r|r|}
\hline \multicolumn{1}{|l|}{ Model } & & Sum of Squares & Df & Mean Square & \multicolumn{1}{c|}{ F } & Sig. \\
\hline & Regression & 122236.849 & 2 & 61118.425 & 810.295 & $.000^{\mathrm{b}}$ \\
& Residual & 49706.647 & 659 & 75.427 & & \\
& Total & 171943.496 & 661 & & & \\
\hline
\end{tabular}

a. Dependent Variable: Underpricing

b. Predictors: (Constant), age of the firm, pre ipo leverage

This table shows the area of significance which is less than 0.05 which proves to be a significant model. F value being high shows that all the variables have significant relationship with each other. 


\section{Coefficients}

\begin{tabular}{|c|c|c|c|c|c|c|}
\hline \multirow{2}{*}{\multicolumn{2}{|c|}{ Model }} & \multicolumn{2}{|c|}{$\begin{array}{c}\text { Unstandardized } \\
\text { Coefficients }\end{array}$} & \multirow{2}{*}{$\begin{array}{c}\text { Standardized } \\
\text { Coefficients } \\
\text { Beta }\end{array}$} & \multirow[t]{2}{*}{$\mathrm{t}$} & \multirow[t]{2}{*}{ Sig. } \\
\hline & & $\mathrm{B}$ & Std. Error & & & \\
\hline \multirow{3}{*}{1} & & 93.854 & 1.525 & & -61.530 & .000 \\
\hline & Age of firm & .931 & .023 & .843 & 40.220 & .000 \\
\hline & Pre ipo leverage & 2.380 & 14.670 & .003 & .162 & .871 \\
\hline
\end{tabular}

a. Dependent Variable: Underpricing

Table shows that value of the firm has played a significant role in this company for underpricing. Age of the firm and pre ipo leverage represents the value of the firm therefore it signifies that high value or high quality firm underprices more than the low value or low quality firm because the latter cannot afford underpricing.

\section{Multi commodity exchange of India}

\begin{tabular}{|c|c|c|c|c|c|c|c|c|c|}
\hline \multicolumn{10}{|c|}{ Model Summary } \\
\hline \multirow[t]{2}{*}{ Model } & \multirow[t]{2}{*}{$\mathrm{R}$} & \multirow{2}{*}{$\begin{array}{c}\mathrm{R} \\
\text { Square }\end{array}$} & \multirow{2}{*}{$\begin{array}{l}\text { Adjusted R } \\
\text { Square }\end{array}$} & \multirow{2}{*}{$\begin{array}{l}\text { Std. Error of } \\
\text { the Estimate }\end{array}$} & \multicolumn{5}{|c|}{ Change Statistics } \\
\hline & & & & & $\begin{array}{c}\text { R Square } \\
\text { Change }\end{array}$ & $\begin{array}{c}\mathrm{F} \\
\text { Change }\end{array}$ & df1 & df2 & $\begin{array}{c}\text { Sig. F } \\
\text { Change }\end{array}$ \\
\hline 1 & $.877^{\mathrm{a}}$ & .769 & .768 & 187.21237 & .769 & 1017.061 & 2 & 612 & .000 \\
\hline
\end{tabular}

a. Predictors: (Constant), index volatility, index. Return

This table shows the relationship between the dependent and the independent variables. $\mathrm{R}$ shows that there is $87.7 \%$ correlation between the dependent and the independent variables. $\mathrm{R}$ square which is $76.9 \%$ shows that in V-MART underpricing there is a close influence by independent variables towards dependent variables i.e., underpricing is closely influenced by age of the firm, issue size, pre IPO leverage, promoters holding post issue, Index return and Beta. This model is significant because it has a significance value less than 0.05 i.e., 0.000 .

\begin{tabular}{|rl|r|r|r|r|r|}
\hline \multicolumn{1}{|c|}{ Model } & & ANOVAa & \\
\hline \multirow{2}{*}{1} & Sum of Squares & \multicolumn{1}{c|}{ Df } & Mean Square & \multicolumn{1}{c|}{$\mathrm{F}$} & Sig. \\
\hline & Regression & 71292886.885 & 2 & 35646443.443 & 1017.061 & $.000^{\mathrm{b}}$ \\
& Residual & 21449665.229 & 612 & 35048.473 & & \\
& Total & 92742552.114 & 614 & & & \\
\hline
\end{tabular}
a. Dependent Variable: Underpricing
b. Predictors: (Constant), index volatility, index. Return

This table tells that this is an apt model used because the degree of significance is below 0.05 . $F$ value is also 1017.061 which states that all variables are interdependent to each other. 


\section{Coefficients}

\begin{tabular}{|c|c|c|c|c|c|c|}
\hline \multirow[t]{2}{*}{ Mode } & & \multicolumn{2}{|c|}{ Unstandardized Coefficients } & \multirow{2}{*}{$\begin{array}{c}\text { Standardized } \\
\text { Coefficients }\end{array}$} & \multirow[t]{2}{*}{$t$} & \multirow[t]{2}{*}{ Sig. } \\
\hline & & B & Std. Error & & & \\
\hline \multirow{3}{*}{1} & (Constant) & -73.356 & 19.889 & & -3.688 & .000 \\
\hline & index.return & .953 & .021 & .877 & 45.101 & .000 \\
\hline & Index volatility & -118.424 & 228.628 & -.010 & -.518 & .605 \\
\hline
\end{tabular}

a. Dependent Variable: Underpricing

The findings of the study indicate that the underpricing increases with significant variables like high return on opening and the beta value. It can now be stated that in capital market, high market conditions underprice more for signaling their high market to their investors. Investors take underpricing as a signal of high market conditions because a low value firm cannot afford leaving money on the table or underpricing. CARE IPO is affected by market condition therefore leads to underpricing

\section{Manappuram Finance limited}

\begin{tabular}{|c|c|c|c|c|c|c|c|c|c|}
\hline \multicolumn{10}{|c|}{ Model Summary } \\
\hline \multirow{2}{*}{$\begin{array}{l}\text { Mode } \\
\text { I }\end{array}$} & \multirow[t]{2}{*}{$\mathrm{R}$} & \multirow{2}{*}{$\begin{array}{c}\mathrm{R} \\
\text { Square }\end{array}$} & \multirow{2}{*}{$\begin{array}{c}\text { Adjusted R } \\
\text { Square }\end{array}$} & \multirow{2}{*}{$\begin{array}{l}\text { Std. Error of } \\
\text { the Estimate }\end{array}$} & \multicolumn{5}{|c|}{ Change Statistics } \\
\hline & & & & & $\begin{array}{c}\text { R Square } \\
\text { Change }\end{array}$ & $\begin{array}{c}\mathrm{F} \\
\text { Change }\end{array}$ & df1 & df2 & $\begin{array}{c}\text { Sig. F } \\
\text { Change }\end{array}$ \\
\hline 1 & $.320^{a}$ & .102 & .092 & 29.93596 & .102 & 10.206 & 2 & 179 & .000 \\
\hline
\end{tabular}

a. Predictors: (Constant), issue size, Index.volatility

There is very less percent of relationship between variables involved. $\mathrm{R}$ shows that there is only 32\% relationship between the dependent and the independent variables. $\mathrm{R}$ square which is $10.2 \%$ shows that in Manappuram finance limied ipo under-pricing there is a very less influence by independent variables towards dependent variables i.e., underpricing is closely influenced by age of the firm, issue size, pre IPO leverage, promoters holding post issue, Index return and Beta. This model is significant because it has a significance value less than 0.05 i.e., 0.000

ANOVAa

\begin{tabular}{|rl|r|r|r|r|r|}
\hline \multicolumn{1}{|l|}{ Model } & & Sum of Squares & Df & Mean Square & \multicolumn{1}{c|}{ F } & Sig. \\
\hline & Regression & 18291.989 & 2 & 9145.994 & 10.206 & $.000^{\mathrm{b}}$ \\
& Residual & 160412.993 & 179 & 896.162 & & \\
& Total & 178704.982 & 181 & & & \\
\hline
\end{tabular}

a. Dependent Variable: Underpricing

b. Predictors: (Constant), issue size, index volitality

The table talks about the significance level that the model is appropriate because it has a significance of 0.00 which is less than 0.05 . 


Coefficients
\begin{tabular}{|ll|r|r|r|r|r|}
\hline Model & & \multicolumn{2}{|c|}{$\begin{array}{c}\text { Unstandardized } \\
\text { Coefficients }\end{array}$} & $\begin{array}{c}\text { Standardized } \\
\text { Coefficients }\end{array}$ & \multicolumn{1}{c|}{$\mathrm{t}$} & \multirow{2}{*}{ Sig. } \\
\cline { 3 - 7 } & \multicolumn{1}{|c|}{$\mathrm{B}$} & \multicolumn{1}{c|}{ Std. Error } & \multicolumn{1}{c|}{ Beta } & & \\
\hline & (Constant) & 2.155 & 16.614 & & .130 & .897 \\
1 & Issue size & -3.642 & .808 & -.322 & -4.507 & .000 \\
& Index volatility & 19.784 & 60.496 & .023 & .327 & .744 \\
\hline
\end{tabular}

a. Dependent Variable: Underpricing

Findings of the study indicate that the under-pricing increases with significant variables like supply and market condition. Issue size is a component of supply and index volatility is a component of market condition. Therefore Manappuram ipos is affected by market factorrs and supply factors which ultimately leads to underpricing

\section{CONCLUSION}

It has been observed from the analysis that value of the firm, liquidity and market condition factors play an important role in influencing underpricing. It has been concluded that market condition factor has played an important role in influencing underpricing of IPO's in most of the firms who has issued IPO's after 2012.Second factors which determine the firms underpricing is the liquidity factor. Third influential factor is a mix of both the market and liquidity factors.

\section{References}

Aydogan, A. (2006). How Persistent Is the Impact of Market Timing on Capital Structure? Journal of Finance, 51(4), 1681-1710.

Baker, M., Taliaferro, R., \& Wurgler, J. (2006). Predicting Returns with Managerial Decision Variables: Is There a Small-Sample Bias? Journal of Finance, 61(4), 1711-1730.

Baker, M., \& Wurgler, J. (2000). The Equity Share in New Issues and Aggregate Stock Returns. Journal of Finance, 55(5), 2219-2257.

Baker, M., \& Wurgler, J. (2002). Market Timing and Capital Structure. Journal of Finance, 57(1), 1-32.

Ball, E., Hui Chiu, H., \& Smith, R. (2011). Can VCs Time the Market? An Analysis of Exit Choice for Venture-backed Firms. Review of Financial Studies, 24, 3105-3138. doi:10.1093/rfs/hhr042

Brav, A., Geczy, C., \& Gompers, P. A. (2000). Is the abnormal return following equity issuances anomalous? Journal of Financial Economics, 56, 209-249.

Butler, A. W., Grullon, G., \& Weston, J. P. (2005). Can Managers Forecast Aggregate Market Returns? Journal of Finance, 60(2), 963-986.

Carhart, M. M. (1997). On Persistence in Mutual Fund Performance. Journal of Finance, 52(1), 57-82.

Carlson, M., Fisher, A. and Giammarino, R. (2006). Corporate Investment and Asset Price Dynamics: Implications for SEO Event Studies and Long-Run Performance. Journal of Finance, 61, 1009-1034. 2

Chan, K., Ikenberry, D. L., \& Lee, I. (2007). Do managers time the market? Evidence from open-market share repurchases. Journal of Banking \& Finance, 31, 2673-2694. doi:10.1016/j.jbankfin.2006.09.017

Chaturvedi, A., Pandey, A., \& Ghosh, S. K. (2006). Firms Financing Through IPOs: A Study of Causal Variables Responsible for Under-Pricing. Vision - The Journal of Business Perspective, 10, 23-33.

Deb, S. G. (2009). Some Insights into IPO Underpricing in India. Vilakshan, XIMB Journal of Management, (September), 1-14. 
Eberhart, A. C., \& Siddique, A. (2002). The Long-Term Performance of Corporate Bonds (and Stocks) Following Seasoned Equity Offerings. Review of Financial Studies, 15(5), 1385-1406. doi:10.1093/rfs/15.5.1385

Elliott, W. B., Koëter-Kant, J., \& Warr, R. S. (2008). Market timing and the debt - equity choice. Journal of Financial Intermediation, 17, 175-197. doi:10.1016/j.jfi.2007.05.002

Fama, E. F. (1998). Market efficiency, long-term returns, and behavioral finance. Journal of Financial Economics, 49, 283-306.

Fama, E. F., \& French, K. R. (1993). Common Risk Factors in the Returns on Stocks and Bonds. Journal of Financial Economics, 33, 3-56.

Ghosh, S. (2006). Underpricing of Initial Public Offerings. Emerging Markets Finance and Trade, 41(6), 45-57.

Gregory, A., Guermat, C., \& Al-Shawawreh, F. (2010). UK IPOs: Long Run Returns, Behavioural Timing and Pseudo Timing. Journal of Business Finance \& Accounting, 37, 612-647. doi:10.1111/j.1468-5957.2010.02182.x 3 